\title{
Vitamin B6 Measurement
}

National Cancer Institute

\section{Source}

National Cancer Institute. Vitamin B6 Measurement. NCI Thesaurus. Code C74901.

The determination of the amount of Vitamin B6 present in a sample. 